\title{
Soil Moisture Characteristic Curves under Various Rice Based Cropping Systems and Fertigation Regimes
}

\author{
Suman Lata*, Anshuman Kohli, Y. K. Singh and Shweta Shambhavi \\ Department of Soil Science and Agricultural Chemistry, Bihar Agricultural College, Bihar \\ Agricultural University, Sabour-813210, Bhagalpur, Bihar, India \\ *Corresponding author
}

Keywords

Soil moisture, Rice, Cropping systems, Fertigation regimes

Article Info

Accepted:

05 February 2020

Available Online:

10 March 2020

\section{A B S T R A C T}

Soil moisture is one of the important factor of soil that directly regulate the growth and development of plants. To manage the water scarcity problem during rabi season in south Bihar, we have to know the available water condition to supply optimum water for the crops. The soil is sandy clay loam, slightly alkaline in reaction $(\mathrm{pH} 7.3)$. The experiment has split plot design having three fertigation levels of nitrogen $(\mathrm{W} 1=25 \% \mathrm{~N}, \mathrm{~W} 2=50 \%$ $\mathrm{N}, \mathrm{W} 3=75 \% \mathrm{~N}$ of RDF) in main plot and 4 cropping systems i.e. Ricewheat, Rice-barley, Rice-chickpea, Rice-lentil in sub plot. In the present study, no significant effect was observed across fertigation regimes and cropping systems in the soil moisture characteristics because soil moisture characteristics curve is more strongly affected by soil texture and physical conditions. The average soil moisture contents $(v / v)$ at field capacity and at permanent wilting point were $33.73 \%$ and $9.56 \%$ respectively.

\section{Introduction}

Lowland rice is cultivated in India in about 14.4 million hectares, which accounts for 32.4 $\%$ of the total area under rice crop in the country (Lal et al., 2017). India primarily depends on rainfed agriculture and the major irrigation in culturable command areas over the IndoGangetic basin is also rainfed (Wani et al., 2009; Droogers et al., 2001). In several districts of south Bihar, most of the farmers grow lowland rainfed rice in kharif and leave the land fallow in rabi due to scarcity of water and this reduces the cropping intensity and productivity. Such situation can be mitigated by facilitating early crop establishment through para / utera cropping to utilize residual soil moisture for germination. If any supplemental water is made available somehow, through rainwater harvesting or 
tapping the groundwater resources, there is prudence in applying the same through efficient delivery mechanisms. This will not only maintain the desirable level of soil moisture in the field but also help improve the nutrient delivery mechanisms, thus modifying the soil water as well as nutrient availability regimes in the soil. The soil moisture regimes simultaneously determine the nutrient availability as well as the root penetrability under different rice based cropping systems and influence water use efficiency. Subbian $e t$ al., (2008) reported that the soil moisture retention was a function of cropping systems and fertilizer levels. Conservation practices also affect the water retention capacity in soil. No tillage improves the percolation rate by 20 to $30 \%$ at $20-40 \mathrm{~cm}$ depth (Acharya et al., 2019). Soil properties play a major role in soil moisture dynamics and for crop growth. Root distribution of various crops accounts for the amount of water required for each crop and also the effective root zone depth (Steduto $e t$ al., 2012). Soil characteristics along with meteorological and crop patterns, describes the changes in surface and root zone soil moisture, temporally and spatially. Along with, root distribution of a crop further influences the sub-surface water content and water uptake as is shown by Monti and Zatta (2009).

\section{Materials and Methods}

The study was conducted in experimental farm of Bihar Agricultural College, Sabour, Bhagalpur falls under the Middle Gangetic plain region of Agro-climatic Zone IIIA considered as sub-humid zone of Bihar. The farm is situated at the geographical coordinates of $24^{0} 13^{\prime} 45^{\prime \prime} \mathrm{N}$ latitude, $87^{0} 02^{\prime}$ $48^{\prime \prime}$ E longitude and an altitude of about $25 \mathrm{~m}$ above mean sea level.is located in sub-tropical climate characterized with hot desiccating summers, cold winters and moderate rainfall. May is the hottest month with an average maximum temperature of 35 to $39^{\circ} \mathrm{C}$. January is the coldest month of the year with mean minimum temperature varying from 5 to $10^{\circ} \mathrm{C}$. The average annual rainfall is $1231.4 \mathrm{~mm}$, precipitating mostly between mid-June to midOctober (during south west monsoon). The soil is sandy clay loam, slightly alkaline in reaction ( $\mathrm{pH}$ 7.3). The experiment has split plot design having three fertigation levels of nitrogen $(\mathrm{W} 1=25 \% \quad \mathrm{~N}, \quad \mathrm{~W} 2=50 \% \quad \mathrm{~N}$, $\mathrm{W} 3=75 \% \mathrm{~N}$ of $\mathrm{RDF}$ ) in main plot and 4 cropping systems i.e. Rice-wheat, Rice-barley, Rice-chickpea, Rice-lentil in sub plot. The recommended dose of fertilizer (RDF) of rainfed rice is $80-40-20 \mathrm{Kg} \mathrm{NPK} \mathrm{h}^{-1}$. Full dose of $\mathrm{P}, \mathrm{K}$ and one- third of $\mathrm{N}$ was applied as basal. The remaining two doses were applied at the stage of active tillering and panicle initiation. This is long term experiment started in 2014 whose main aim to increase intensification and diversification in lowland of south Bihar by utilizing residual moisture after kharif rice.

Undisturbed soil samples were collected through core sampler in various rings from surface soil. These samples were analyzed through pressure plate apparatus as described by Klute (1986).

\section{Results and Discussion}

Table 1shows the equilibrium soil moisture content at various soil moisture suction levels for different fertigation regimes and cropping systems. In the present study, no significant effect was observed across fertigation regimes and cropping systems in the soil moisture characteristics because soil moisture characteristics curve is more strongly affected by soil texture and physical conditions. With same texture of the field and little difference in soil physical conditions over the past five years, the soil moisture characteristics were found to be statistically similar across various fertigation regimes and cropping systems as shown in fig. (1) \& fig. (2) respectively. 
Table.1 Effect of fertigation regimes and rice based cropping systems on soil moisture content $(v / v, \%)$ at different pressure of surface soil during 2018 at BAC, Sabour

\begin{tabular}{|c|c|c|c|c|c|c|c|c|c|c|}
\hline $\begin{array}{c}\text { Treatments/Pres } \\
\text { (Bar) Fertigation (F) }\end{array}$ & 0.3 & 0.7 & 1 & 2 & 4.5 & 5.5 & 7 & 10 & 12 & 15 \\
\hline $\mathrm{N}_{20} \mathrm{fb} 200 \mathrm{~mm}$ & 33.32 & 28.95 & 27.85 & 21.41 & 22.12 & 20.85 & 17.71 & 13.61 & 10.42 & 9.45 \\
\hline $\mathrm{N}_{40} \mathrm{fb} 300 \mathrm{~mm}$ & 35.04 & 28.93 & 27.53 & 20.49 & 22.17 & 20.30 & 18.22 & 13.68 & 10.85 & 9.92 \\
\hline $\mathrm{N}_{60} \mathrm{fb} 400 \mathrm{~mm}$ & 32.82 & 29.02 & 28.15 & 21.02 & 23.05 & 20.31 & 17.88 & 12.43 & 11.54 & 9.32 \\
\hline Mean & 33.73 & 28.97 & 27.85 & 20.97 & 22.45 & 20.49 & 17.94 & 13.24 & 10.94 & 9.56 \\
\hline CD (5\%) & NS & NS & NS & NS & NS & NS & NS & NS & NS & NS \\
\hline \multicolumn{11}{|l|}{$\begin{array}{r}\text { Cropping } \\
\text { systems(CS) }\end{array}$} \\
\hline Rice- Durum wheat & 33.84 & 29.39 & 28.74 & 21.31 & 22.64 & 20.57 & 18.45 & 13.01 & 10.34 & 9.77 \\
\hline Rice- Barley & 34.42 & 28.83 & 27.84 & 21.82 & 22.95 & 19.80 & 17.35 & 13.64 & 11.00 & 9.29 \\
\hline Rice- Chickpea & 33.61 & 28.81 & 27.33 & 20.30 & 21.43 & 22.20 & 17.63 & 12.57 & 11.31 & 9.43 \\
\hline Rice- Lentil & 33.03 & 28.83 & 27.47 & 20.46 & 22.78 & 19.38 & 18.32 & 13.73 & 11.10 & 9.76 \\
\hline Mean & 33.73 & 28.97 & 27.85 & 20.97 & 22.45 & 20.49 & 17.94 & 13.24 & 10.94 & 9.56 \\
\hline CD $(5 \%)$ & NS & NS & NS & NS & NS & NS & NS & NS & NS & NS \\
\hline
\end{tabular}

$\mathrm{N}_{20}$ fb $200 \mathrm{~mm}=\mathrm{N} @ 20 \mathrm{~kg} \mathrm{ha}^{-1}$ in rice through fertigation followed by $200 \mathrm{~mm}$ irrigation through inline drip system in post-rice crops $\mathrm{N}_{40}$ fb $300 \mathrm{~mm}=\mathrm{N} @ 40 \mathrm{~kg} \mathrm{ha}^{-1}$ in rice through fertigation followed by $300 \mathrm{~mm}$ irrigation through inline drip system in post-rice crops $\mathrm{N}_{60} \mathrm{fb} 400 \mathrm{~mm}=\mathrm{N} @ 60 \mathrm{~kg} \mathrm{ha}^{-1}$ in rice through fertigation followed by $400 \mathrm{~mm}$ irrigation through inline drip system in post-rice crops 
Fig.1 Effect of fertigation regimes (a) $\mathrm{N}_{20} \mathrm{fb} 200 \mathrm{~mm}$ (b) $\mathrm{N}_{40} \mathrm{fb} 300 \mathrm{~mm}$ (c) $\mathrm{N}_{60} \mathrm{fb} 400 \mathrm{~mm}$ on soil moisture characteristics curve
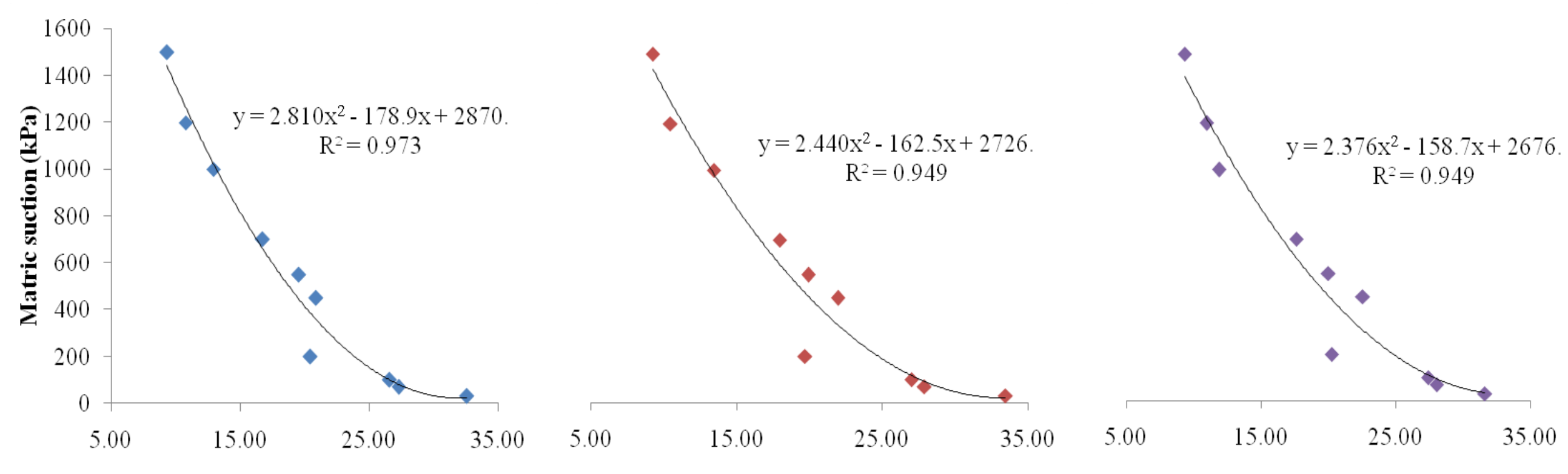

Volumetric moisture content $(\%)$ 
Fig.2 Effect of cropping systems (a) rice- durum wheat (b) rice- barley (c) rice-chickpea (d) rice- lentil on soil moisture characteristics curve

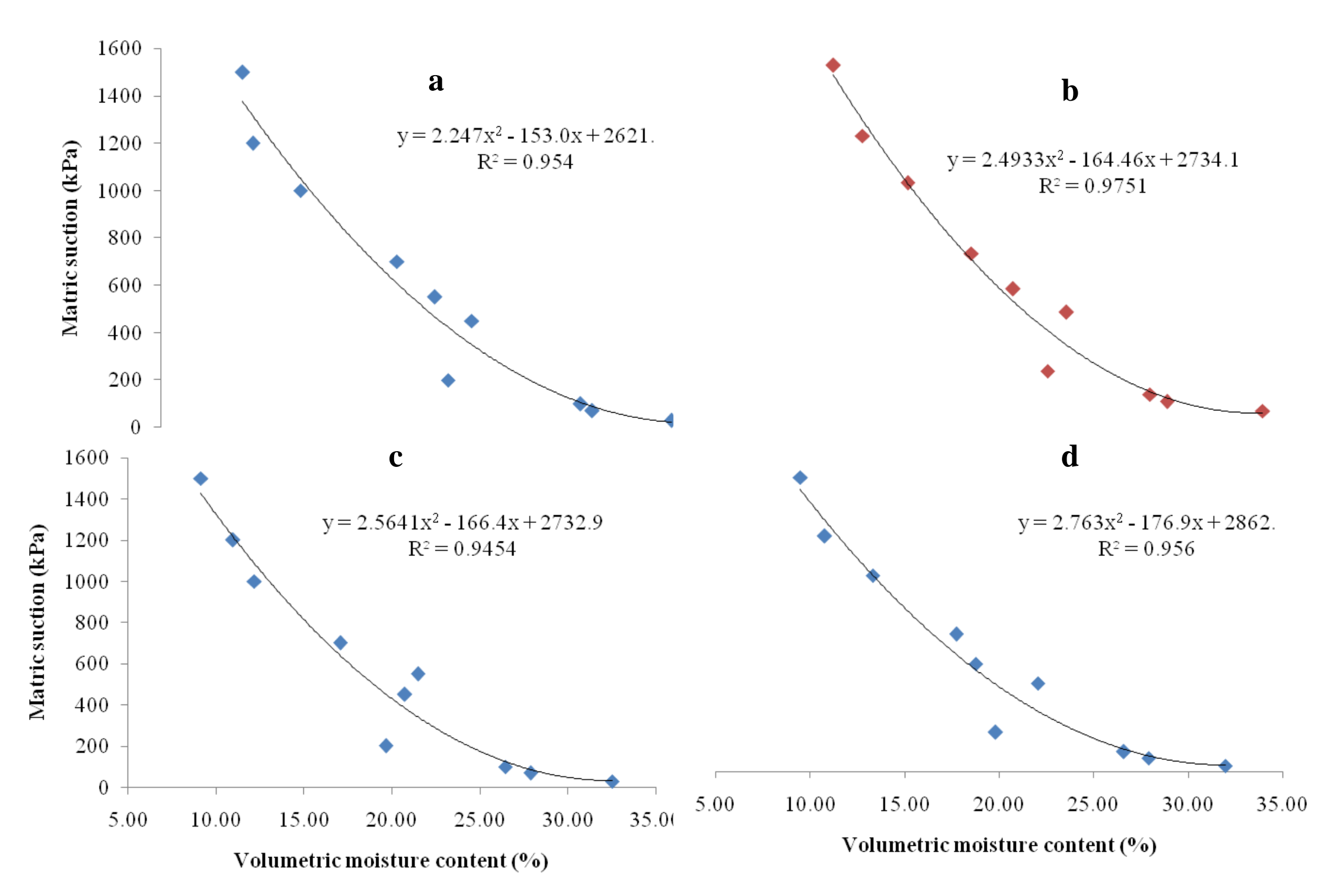


As the matric potential increased, the water content decreased. Further, the water retained at lower tensions is dependent on soil structure, whereas at higher tensions it is dependent on particle-size distribution and soil mineralogy (Shwetha and Varija, 2015). The slight differences in moisture content at same pressure across various fertigation regimes and cropping systems might be due to differences in pore size distribution and soil compaction. The average soil moisture contents $(v / v)$ at field capacity and at permanent wilting point were $33.73 \%$ and $9.56 \%$ respectively.

In conclusion, this study evaluated the soil moisture characteristic curve are not strongly affected by cropping system and different level of fertigation. So, we have concluded that the effect on soil moisture curve is not seen in short term experiment but it may give better result after long term experiment.

\section{References}

Acharya, B. S., Dodla, S., Gaston, L. A., Darapuneni, M., Wang, J. J., Sepat, S., Bohara, H., 2019, Winter cver crops effect on sil moisture and soybean growth and yield under different tillage systems, Soil and Tillage Research, Vol 195, 104430.

Droogers, P., Seckler, D., Makin, I., 2001, Estimating the Potential of Rain-fed Agriculture. pp. 21.

Klute, A., 1986, Water retention: Laboratory methods. In: Klute, A., Ed., Methods of
Soil Analysis, Part 1, Physical and Mineralogical Methods, ASA and SSSA, Madison, 635-662.

Lal, B., Gautam, P., Panda, B. B., Raja, R., Singh, T., Tripathi, R., Shahid, M., Nayak, A. K., 2017, Crop and varietal diversification of rainfed rice based cropping systems for higher productivity and profitability in Eastern India.

Monti, A., Zatta, A., 2009, Root distribution and soil moisture retrieval in perennial and annual energy crops in Northern Italy. Agric. Ecosyst. Environ. 132, 252-259.

Shwetha, P., Varija, K., 2015, Soil water retention curve from saturated hydraulic conductivity for sandy loam and loamy sand textured soils, Aquatic Procedia, 4, 1142 - 1149 .

Steduto, P., Hsiao, T.C., Fereres, E., Dirk, 2012, Crop Yield Response to Water (No. 66). Fao Irrigation and Drainage Paper. Food and Agriculture Organization of the United Nations, Rome.

Subbian, P., Lal, R., Akala, V., 2008, LongTerm Effects of Cropping Systems and Fertilizers on Soil Physical Properties, Journal of Sustainable Agriculture, Vol. 16(2) 2000.

Wani, S. P., Rockström, J., Oweis, T., 2009. Rainfed Agriculture Unlocking the potential. Pdf. Centre for Agriculture and Bioscience International, London, UK.

\section{How to cite this article:}

Suman Lata, Anshuman Kohli, Y. K. Singh and Shweta Shambhavi. 2020. Soil Moisture Characteristic Curves under Various Rice Based Cropping Systems and Fertigation Regimes. Int.J.Curr.Microbiol.App.Sci. 9(03): 60-65. doi: https://doi.org/10.20546/ijcmas.2020.903.007 